\title{
NEXT EVOLUTION ZONE' AS AN INDICATOR OF PRESCHOOL CHILD CAPABILITY DEVELOPMENT
}

\author{
Eva S̆MELOVÁ
}

\begin{abstract}
This article will help the reader to understand the ,Vygot next evolutiont zone process' and its practise use in preschool child capability development in order to start the compulsary school education.
\end{abstract}

Key words: preschool child, maternity school, maturation, next development zone, capabilities, preschool education, curriculum.

\section{ZÓNA NEJBLIŽŠÍHO VÝVOJE JAKO UKAZATEL ROZVOJE SCHOPNOSTÍ DÍTĚTE PŘEDŠKOLNÍHO VĚKU}

Resumé: Prostřednictvím př́spěvku se čtenář blíže seznámí s Vygotského konstruktem zóny nejbližšího vývoje a jeho využití v rozvoji schopností dítěte předškolního věku ve vztahu $\mathrm{k}$ připravenosti k zahájení povinné školní docházky.

Klićcová slova: dítě předškolního věku, mateřská škola, zrání, učení, zóna nejbližšího vývoje, schopnosti, předškolní vzdělávání, kurikulum.

\section{1 Úvod}

Od roku 1990 prochází institucionální předškolní výchova zásadními změnami, které souvisejí s celkovou proměnou školy. Období 1990 - 2013 lze rozdělit do několika etap, které charakterizují vývoj předškolní výchovy po roce 1990 u nás.

Roky 1990 - 2001 jsou obdobím hledání nových př́stupů. Po zrušení závaznosti Programu výchovné práce pro jesle a mateřské školy lze identifikovat tři přístupy v práci mateřských škol. Objevují se snahy o vytvoření vlastních programů. Učitelky hledají inspiraci zejména $\mathrm{v}$ zahraničních programech alternativně zaměřených (Montessori, Waldorf atd.). V této době začínají vznikat nové inovativní programy, jejichž filozofii některé mateřské školy přijímají za svou (Kurikulum podpory zdraví, Step by Step atd.). Třetí skupinu, i když ne př́liš početnou tvořily učitelky, které se domnívaly, že pro děti je nejpř́nosnější, pokud vše přenechají na jejich volbě, nebudou plánovat a na děti budou pouze dohlížet. Tento prístup se ukázal záhy jako nevyhovující, nebot' děti potřebují podněty, připravené podmínky pro vlastní rozvoj apod.

V tomto období jsou školám zprostředkovány výsledky grantového projektu zaměřeného na „Osobnostně orientovaný model předškolni výchovy" (MŠMT 1993). Učitelky jsou seznámeny s prací $\mathrm{v}$ tomto pojetí a začínají ho postupně implementovat do vlastní pedagogické práce.

V roce 2001 je vydaná první verze Rámcového vzdělávacího programu pro předškolní vzdělávání (dále RVP PV), začíná tak druhá etapa, kterou lze ohraničit roky 2001 2007. Je to období poznávání a ověřování nových př́stupů $\mathrm{k}$ předškolnímu vzdělávání v pojetí osobnostně orientované výchovy. Učitelky hledají vlastní přistupy práce, přemýšlejí o filozofii školního vzdělávacího programu, o zaměření mateřské školy, systému projektování apod.

V zář́ 2007 se stává nové kurikulum závazné. Učitelky navazují na předchozí zkušenosti, pracují podle školních vzdělávacích programů, důsledně zpracovaných $\mathrm{v}$ souladu s RVP PV. Získávají nové zkušenosti a postupně dochází ke stabilizaci jejich práce. V současné době prochází kurikula revizí.

\section{Specifika současného předškolního vzdělávání}

Mateřské školy dnes pracují s moderním kurikulem, které staví na první místo dítě jeho zájmy a potřeby. Při tvorbě kurikula byly využity poznatky, výsledky grantových projektů „Osobnostně orientovaný model předškolní výchovy“ (MŠMT 1993), „Kurikulum mateřské školy se zaměřením na výchovu ke zdravému způsobu života“ (RS 9809, MŠMT 1999), 
mezinárodního programu „Začít spolu“ (Step by Step), výsledky mezinárodního projektu OECD „Thematic Review of Early Childhood Education and Care Policy“ (RS 99006, MŠMT 2000), výsledky veřejné diskuse $\mathrm{k}$ Národnímu programu rozvoje vzdělávání v České republice (MŠMT 2000), doplněné studiem některých zahraničních i domácích kurikulárních dokumentů i dalších pramenů. (RVP PV, 2006, s. 1)

„Rámcový vzdělávaci program pro předškolni vzděláváni vymezuje hlavni požadavky, podminky a pravidla pro institucionálni vzdèláváni dètí předškolniho věku. Tato pravidla se vztahuji na pedagogické činnosti probihajici ve vzdělávacich institucích zařazených do sitě škol a školských zařizení. Jsou závazná pro předškolni vzděláváni $v$ mateřských školách, $v$ mateřských školách sprogramem upraveným podle speciálnich potřeb dětí a v prípravných tř́dách základnich škol. Stanovuje elementárni vzdělanostni základ, na který může navazovat základni vzdèláváni, a jako takový predstavuje zásadní východisko pro tvorbu školnich vzdělávacích programi $i$ jejich uskutečňováni. “ (RVP PV, 2006, s. 3)

Současné kurikulum tvoří východisko pro tvorbu školních vzdělávacích programů. $\mathrm{V}$ podobě klíčových kompetencí a očekávaných výstupů jsou formulovány dovednosti, schopnosti, žádoucí chování atd., to znamená, vše podstatné co by si dítě mělo osvojit v rámci svých možností před nástupem do základní školy. Klíčové kompetence a očekávané výstupy můžeme chápat jako ukazatele připravenosti dítěte k zahájení povinné školní docházky. Setkáváme se s názory, že mateřská škola nepřipravuje děti na školu. S tímto tvrzením se nelze ztotožnit, nebot' děti připravujeme pro život, do něhož vstup do školy neodmyslitelně patří. Domníváme se, že podstatná je forma předškolního vzdělávání, jejímž základem jsou hrové činnosti, podnětné prostředí v souladu se zájmy a potřebami dítěte a s důrazem na jeho individualitu. Nové pojetí předškolního vzdělávání vytváří prostor pro výzkum, který je $\mathrm{v}$ současné době $\mathrm{v}$ daném kontextu stále nedostatečný.

\section{Nové pojetí předškolního vzdělávání - výzva pro výzkum}

Dosavadní výzkumy prováděné v oblasti předškolní výchovy ukazují, že institucionalizované předškolní vzdělávání má svůj pozitivní dopad na rozvoj osobnosti dětí. Pozitivní vliv spatřujeme nejenom v oblasti kognitivního vývoje dětí, ale i v oblasti sociální atd.

$\mathrm{Na}$ PdF UP v Olomouci jsme realizovali v roce 2009 - 2013 mezinárodní výzkum, v němž jsme se zaměřili na připravenost dětí $k$ zahájení povinné školní docházky v kontextu současného kurikula, a to v podmínkách ČR, Slovenska a Slovinska.

Potřebná data jsme získali prostřednictvím aplikace deseti testových úkolů, které byly sestaveny ze standardních psychologických nástrojů. Výzkumný soubor tvořilo 931 českých dětí prredškolního věku, které $\mathrm{v}$ příslušném roce byly u zápisu do prvních tříd, a to $\mathrm{v}$ rozmezí od 5 let a 5 měsíců věku do 7 let a 10 měsíců věku.

Ve všech sledovaných oblastech děti dosáhly průměrných výsledkủ, někdy se blížily spíše $\mathrm{k}$ dolní hranici průměru. Uvedené skutečnosti nás zcela přirozeně nutí k zamyšlení se nad možnými př́íčinami. Zcela logicky vyvstává otázka ,zda je skutečně dětský potenciál rozvíjený v rámci možností ditěte? "

\section{Vývojové změny - proces interakce zrání a učení}

Většina psychologů, kteří se zabývají kognitivním vývojem, se shoduje, že vývojové změny přímo souvisejí s procesem zrání ,,nature“ a učení „nurnature“. I když každý z nich přikládá procesu zrání a učení jinou váhu. Např́klad J. Piaget tvrdil, že změny v dětském poznávání souvisejí zejména s procesem zrání, spíše než v souvislosti s prostředím, které může $\mathrm{v}$ rozvoji jedince pomáhat nebo brzdit. Z praxe mateřských škol známe př́pady, kdy do mateřské školy přijde dítě, které se jeví na svůj věk nedostatečně rozvinuté. Při bližším posouzení celé situace se např. ukáže, že rodina dítěti nevěnuje dostatečnou pozornost. $V$ tomto príípadě je zřejmý špatný vliv rodiny. Iniciativu následně přebírá instituce a snaží se dítěti pomoci. Učitelky v podstatě napravují chyby, které způsobilo nepodnětné rodinné prostředí.

S odlišným př́stupem se setkáváme u Vygotského, který považuje prostředí za významný faktor v intelektuálním vývoji dítěte. Na rozdíl od Piageta podle Vygotského probíhá většinou dětské učení prostřednictvím interakce s prostředím, které $\mathrm{v}$ podstatě předurčuje, co si dítě zvnitřní. (Sternberg, R., J. 2009)

$\mathrm{V}$ rámci našeho výzkumu jsme provedli komparaci dat získaných u našich dětí (2009 2012) s daty studie Kořínka, který v roce 1975 prezentoval vlastní výzkum, v němž se zabýval školní připraveností. Zajímalo nás, zda se tento 
více jak třicetiletý časový odstup, kdy dítě vyrůstá $\mathrm{v}$ jiných společenských podmínkách, $\mathrm{s}$ nimiž př́mo souvisí charakter rodinné výchovy, prochází odlišným institucionalizovaným předškolním vzděláváním apod., se projeví v některé ze sledovaných oblastí. Komparace ukázala pouze minimální rozdíly, což potvrzuje význam procesu zrání.

Úspěšnost zahájení povinné školní docházky tedy ovlivňuje nejenom biologická zralost, ale i zralost v oblasti kognitivní, citové a sociální. Zcela logicky za nejdůležitější z hlediska vlivu prostředí považujeme výchovu v rodině, podnětnost rodinného prostředí, její bezpečné a emocionální zázemí zajištující primární socializaci.

Socializaci nechápeme pouze jako vnějšš projevy chování, ale zejména socializaci vnitřního proživání, které ovlivňuje emoční vývoj dítěte úzce související s jeho celkovým rozvojem. V období $3-6$ let vstupuje mnoho dětí do dětského kolektivu mateřské školy. I když výzkumy provedené v ČR „neprokázaly jednoznačnou výhodu návštěvy predškolniho zařizeni", (Langmeier, J., Krejčířová, D., 2006, s. 109), domníváme se, že předškolní vzdělávání významně přispívá $\mathrm{k}$ všestrannému rozvoji dítěte.

\section{Zóna nejbližšího vývoje}

V návaznosti na náš výzkum se zamýšlíme nad vhodnými přístupy souvisejícími s rozvojem učebního potenciálu dítěte. Jak již avizuje samotný název př́spěvku, inspiraci můžeme nalézt ve Vygostkého konceptu zóny nejbližšího vývoje.

Zónu nejbližšího vývoje popsal Vygotský jako rozpětí mezi výkonem dítěte a jeho latentní kapacitou, která není zřejmá. Vychází $\mathrm{z}$ předpokladu, že $\mathrm{v}$ rámci vývoje kognitivních schopností dítěte existují úlohy, které je dítě schopné úspěšně řešit, ale existují i úlohy, které zvládne pouze s dopomocí dospělého. Nejsou ale príliš vzdálené od zóny nejbližšího vývoje.

Pracuje-li učitel s dětmi na základě znalosti jejich zóny nejbližšího vývoje, kterou diagnostikuje, rozvíjí dětský potenciál $\mathrm{v}$ souladu $\mathrm{s}$ jejich možnostmi. Dítě není podceňováno ani prètěžováno. Vygotský ukázal, jak lze latentní kapacitu dítěte měřit. Za nevhodné považoval hodnocení dětí ve statickém hodnotícím prostředí, kde základem jsou pouhé otázky a odpovědi, tedy na co dítě dokáže odpovědět správně, co nezná, neví.

Hodnocení podle Vygotského by mělo probíhat v dynamickém hodnotícím prostředí, $\mathrm{v}$ němž pedagog $\mathrm{s}$ odpovědí dítěte pracuje, a to tak, že plynule přejde k řešení problému. Stává se průvodcem dítěte, kterému poskytuje rady s cílem usnadnit mu nalézt cestu řešení. To jak dítě dokáže využít rady pedagoga, učiteli ukazuje, jaké schopnosti dítě má nad rámec pozorovaného. Popsaný př́stup tvoří základ měření zóny nejbližšího vývoje, který lze využít i v praxi mateřských škol.

K měření zóny nejbližšího vývoje vznikly i testy, k nejznámějším patř́i Feuersteinův (1979) Learning Potential Assessment Device (nástroj na stanovení učebního potenciálu). Podle Feuersteina není rozumový potenciál neměnnou charakteristikou. Podstata spočívá ve zjištění, do jaké míry lze schopnosti člověka rozvíjet a jaké prostředky je nutné využít.

Doposud jsme hovořili zejména o zóně nejbližšího vývoje, kterou je třeba znát pro optimální rozvoj dítěte. $\mathrm{K}$ tomu ale potřebuje pedagog znát výkon dítěte, tj. jeho aktuální zónu a postupně zjištuje, co je dítě schopno zvládnout $\mathrm{s}$ jeho dopomocí. Zajímá se současně o využití vhodných vzdělávacích prostředků.

Koncept zóny nejbližšího vývoje využivá dynamická diagnostika učebních schopností. Představuje metodu, kterou lze využít $\mathrm{v}$ rámci pedagogické diagnostiky učitelky mateřské školy. Mertin, V. a Krejčová, L. a kol.(2012) uvádějí, že tato metoda je v podmínkách českého školství používaná spíše výjimečně, jiná situace je napřr. v USA nebo ve Velké Británii. I když i zde je spíše využívaná psychology.

Pokud vezmeme vúvahu, že dynamická diagnostika je procesem dlouhodobým, potom je zcela logické, že ji mohou využívat učitelé, kteří jsou s dětmi skoro denně, děti velmi dobře znají a mohou tak posuzovat potenciál dítěte, jeho možnosti a limity a $\mathrm{v}$ prímé souvislosti těchto poznatků dítě rozvíjet.

Dynamický př́stup může velmi vhodně obohatit využívané vzdělávací strategie. Od učitele tento prrístup vyžaduje přemýšlení o každém dítěti, jeho výkonech, možnostech, problémech apod. Při plnění různých úkolů by měl být dítěti průvodcem, kdy za využití vhodných otázek a s oporou základních předpokladů, které specifikovali Mertin, V., Krejčová, L. a kol.(2012), rozvíjí dětský potenciál.

Mertin, V., Krejčová, L. a kol. (2012) upozorňují, že výchozím předpokladem je, uvědomit si, že schopnosti dítěte nejsou stabilní, neměnné. Pro učitelky mateřské školy to znamená, že není důležité pouze to, co dítě umí, ale musí přemýšlet o jeho možnostech v kontextu stanovených 
klíčových kompetencí RVP PV, které představují určitou metu v předškolním vzdělávání, tedy před nástupem do primární školy. S tím souvisí i hodnocení dítěte, kde sledujeme, $v$ čem se dítě zlepšuje, jaké dosahuje pokroky.

Dalším předpokladem je individualizace ve vzdělávání, kdy se učitelka zabývá každým dítětem, přemýšlí o jeho zájmech, potřebách, možnostech atd. Učitelka se dále orientuje na myšlenkové procesy, jejichž prostřednictvím dítě dospělo k výkonu. Zamýšlí se nad postupem dítěte, nad chybami, které se při řešení objevovaly, nad schopností soustředit se apod. V práci učitelka využívá úkoly podporující rozvoj myšlení, obohacuje myšlenkové a pracovní strategie. Učitelka nezapomíná na zpětnou vazbu a práci s chybou, která představuje zdroj pro další vývoj dítěte.

\section{Závěr}

Vygotského pojetí zóny nejbližšího vývoje lze chápat jako inspirační zdroj, který můžeme vhodně využít i $\mathrm{v}$ předškolním vzdělávání. Osvojení tohoto př́stupu pomůže učitelům v rozvoji rozumových schopností (intelektu) dítěte v kontextu jeho potenciálu, v souladu s požadavky RVP PV a s požadavky, které souvisejí se zahájením povinné školní docházky. Domníváme se, že je to možná cesta ke zefektivnění vzdělávacího procesu, se zohledněním skutečných možností dítěte, tedy s maximálním využitím dětského potenciálu, a to s ohledem na individuální zvláštnosti každého jedince.

\section{Literatura}

[1] LANGMEIER, J., KREJČÍŘOVÁ, D. Vývojová psychologie. Praha: GRADA, 2006. ISBN 80-247-1284-9. s. 368
[2] MAREŠ, J. Pedagogická psychologie. Praha: Portál, 2013. ISBN 978-80-262-0174-8. s. 702.

[3] MERTIN, V, KREJČOVÁ, L. a kol. Metody a postupy poznávání žáka. Wolters Kluwer, ČR, 2012. ISBN 978-80-7357-679-0. s. 343.

[4] STERNBERG, R. J. Kognitivní psychologie. Praha: Portál, 2009. ISBN 978-80-7367-638-4. s. 636.

[5] ŠMELOVÁ, E., PETROVÁ, A., SOURALOVÁ, E., et al., et al. Připravenost dětí $k$ zahájení povinné školni docházky $v$ kontextu současného kurikula. Olomouc: Univerzita Palackého v Olomouci, 2012. ISBN 978-80-2443345-5. s. 311.

[6] ŠMELOVÁ, E., PETROVÁ, A., SOURALOVÁ, E., et al. Pre-school education in the context of curriculum children's readiness for compulsory school attendance in the context of selected EU countries - Czech Republic, Slovakia, Slovenia. Olomouc: Palacký University Olomouc, 2012. ISBN 978-80-244-3370-7. s. 243.

[7] VYGOTSKIJ, L. S. Psychologie myšleni a řec. Praha: Státní pedagogické nakladatelství, 1976. s. 295.

[8] Rámcový vzdělávací program pro předškolní vzdélávání. Praha: VÚP, 2006. ISBN 80-8700000-5. s. 48.

doc. PhDr. Eva Šmelová, Ph.D.

Katedra primární a preprimární pedagogiky

Pedagogická fakulta UP

Žižkovo nám. č. 5

77140 Olomouc, ČR

Tel: +420 585635105

E-mail: eva.smelova@upol.cz

Www pracoviště: www.kpv.upol.cz 